\title{
Rice Growth, Grain Zinc, and Soil Properties under Saline Irrigation Conditions
}

\author{
Lan Phuong Dinh Thi ${ }^{1 *}$, Nga Nguyen Thi Hang ${ }^{1}$, Hoa Thanh Nguyen', \\ Lien Thi Nguyen' \\ 1 Thuyloi University, 175 Tay Son str., Dong Da, Ha Noi, Vietnam \\ * Corresponding author's email: dinhlanphuong@tlu.edu.vn
}

\begin{abstract}
This research evaluated rice growth and yield as well as $\mathrm{Zn}$ accumulation in both soil and grain under saline water irrigation conditions. The experiment consisted of a series of pots containing rice plants and paddy soil, with the application of irrigation treatments of five different salinity levels $(1.5,2,3,4$, and 5\% with a drip irrigation system). The results show that the salinity accumulation levels in soil can increase by up to $2.8 \%$ o following the application of 5\% salinity irrigation water during the development stages. Besides, this study also aimed to evaluate the influences of saline water irrigation on the observed rice yields, plant height, leaf length, and leaf width. In the results, irrigation with 3\%o saline water reduced potential rice yield by $58.6 \%$ and the length of rice leaves by one-third. Higher salinity of $4 \%$ in the irrigation water produced only $24 \%$ of average potential productivity, and 5\% water salinity resulted in no yield. Furthermore, salt stress limited the mobile $\mathrm{Zn}$ content in paddy soil, reducing the $\mathrm{Zn}$ accumulation in grains by between $36.27 \%$ and $83.21 \%$. Thus, the study shows that controlling salinity in irrigation water management is essential for controlling the yield and nutrient $\mathrm{Zn}$ content in rice grains.
\end{abstract}

Keywords: salt stress, rice growth, nutrient zinc, irrigation water, salt accumulation.

\section{INTRODUCTION}

Saline intrusion is an increasing problem for the water irrigation systems in Vietnam. Water scarcity in the dry season due to the effects of climate change leads to increased salinity levels in the main irrigation system in some areas (Mekong Delta, Bac Hung Hai), contributing to worsening paddy cultivation conditions and potentially affecting millions of hectares of rice fields with a loss of productivity. Since 2010, salinisation has been recorded as increasing annually by about $1-2 \%$ of the area of agricultural soil in the Mekong Delta, with the highest level of salt recorded at 4\%o [Vietnam's Directorate of Water Resources, 2020].

Salinity can have a negative impact on agricultural production, seriously affecting rice production and food security, and also damaging the economy. For instance, the Bac Hung Hai irrigation system in the Red River Delta in North Vietnam, one of the primary sources of irrigation water for the region, has been impacted by salinity intrusion. In addition, the Ke Go reservoir in central Vietnam contained only 70 million $\mathrm{m}^{3}$ out of a potential 345 million $\mathrm{m}^{3}$ water in 2019 , which is equivalent to one-fifth of the total volume the system was designed to hold [Vietnam's Directorate of Water Resources, 2020]. Other provinces in the Mekong Delta exhibited saline intrusion up to 80-90 m into agricultural soils in 2019 and 2020 [Vietnam's Directorate of Water Resources, 2020]. However, many rice cultivation areas have no choice but to use saline water sources for irrigation when there is no alternative water source. Although solutions using different cultivation techniques to increase salinity tolerance in rice have been proposed, including saline-tolerant rice varieties and repletion of irrigation sources, the results have yet to be proven effective in terms of yield and quality.

Drought has similarly exacerbated abiotic stresses, leading to considerable harvest reductions in major cereal species, including wheat, 
maize, rice, and barley [Carmen \& Roberto, 2011]. Favourable conditions for optimal rice cultivation include a soil $\mathrm{pH}$ value from 4.5-7.5, electrical conductivity (EC) $<4 \mathrm{mS} / \mathrm{cm}$, exchangeable sodium percentage $<15$, and sodium absorption coefficient (SAR) $<15$ [Bohn et al., 1985].

Rice plants are very sensitive to changes in salinity. Moreover, rice during the seedling stage is more sensitive to salinity stress than during the tillering stage [Hussain et al., 2017]. Most rice varieties are only salt-tolerant at EC $<3.0 \mathrm{mS} / \mathrm{cm}$ in soil and EC $<2.0 \mathrm{mS} / \mathrm{cm}$ in water [Kibria et al., 2017]. A thorough review of the available literature shows that saline stress in soil or water can increase leaf ageing and reduce the nutrient uptake [Munns \& Tester, 2008], subsequently inhibiting rice growth and grain productivity [Carmen B. \& Roberto, 2011; Chawla S. et al., 2013]. Specifically, the $\mathrm{NaCl}$ accumulation at high levels, which increases the concentration of $\mathrm{Na}^{+}$and $\mathrm{Cl}^{-}$ions in the plant epithelium, is one of the more detrimental effects of saline stress [Maathuis, 2014]. These ions cause the rate of leaf ageing to be faster than the growth cycle of the plant, resulting in poor absorption of essential minerals, including $\mathrm{Zn}$, and increased uptake competition with $\mathrm{K}^{+}, \mathrm{Ca}^{2+}$, $\mathrm{Mg}^{2+}$, and $\mathrm{NO}_{3}^{-}-\mathrm{N}$ nutrient ions [Flowers \& Colmer, 2008]. This, in turn, negatively affects plant leaf length, stem height, and crop yield, as well as the $\mathrm{Zn}$ nutrition content in soil which can then reduce the $\mathrm{Zn}$ content in the rice grains.

In this study, the growth of rice plants, the $\mathrm{Zn}$ content in the grain, and mobile $\mathrm{Zn}$ concentration were examined in soils under saline irrigation conditions, to further explain the disbenefits of salt accumulation. The results of saline accumulation during the spring and summer seasons of 2019, and the consequent effects in the spring 2020 season on growth and productivity of rice, mobile $\mathrm{Zn}$ content in the soil, and grain $\mathrm{Zn}$ content were also examined. The experiments were all conducted under greenhouse conditions. The results of this study will improve the understanding of the influences of salinity on rice growth, mobile $\mathrm{Zn}$ reduction in paddy soil, and also reduced $\mathrm{Zn}$ accumulation in grains.

\section{MATERIALS AND METHODS}

\section{Reagents}

In order to extract mobile $\mathrm{Zn}$ from the soils, diethylenetriamine pentaacetate $(0.025 \mathrm{~mol} / \mathrm{L}$ of DTPA), triethanolamine $(0.5 \mathrm{~mol} / \mathrm{L}$ of TEA), and calcium chloride $\left(0.05 \mathrm{~mol} / \mathrm{L}\right.$ of $\left.\mathrm{CaCl}_{2}\right)$ were used, purchased from Merck (Germany). Sodium chloride $99.99 \% \mathrm{NaCl}$ (Duc Giang, Vietnam) was used for mixing salt irrigation water; and $30 \% \mathrm{H}_{2} \mathrm{O}_{2}, 98 \% \mathrm{HNO}_{3}$, and $37 \% \mathrm{HCl}$ (Xichlong, China) were used in $\mathrm{Zn}$ extraction.

\section{Experimental areas, variety, and sampling}

\section{Date and location of study}

The experiments were conducted under greenhouse conditions at the Vietnam National University of Agriculture, Gia Lam, Ha Noi, Vietnam (210'21.918" N, 10549'28.928" E), between February 2019 and May 2020. The study areas were 0.02 hectares in size, and included three rice crops during each of the two spring and one summer seasons (Figure 1).

\section{Variety}

A popular rice variety in Vietnam, HT8, was chosen for the experiments. This rice is widely grown in the northern provinces of Vietnam.

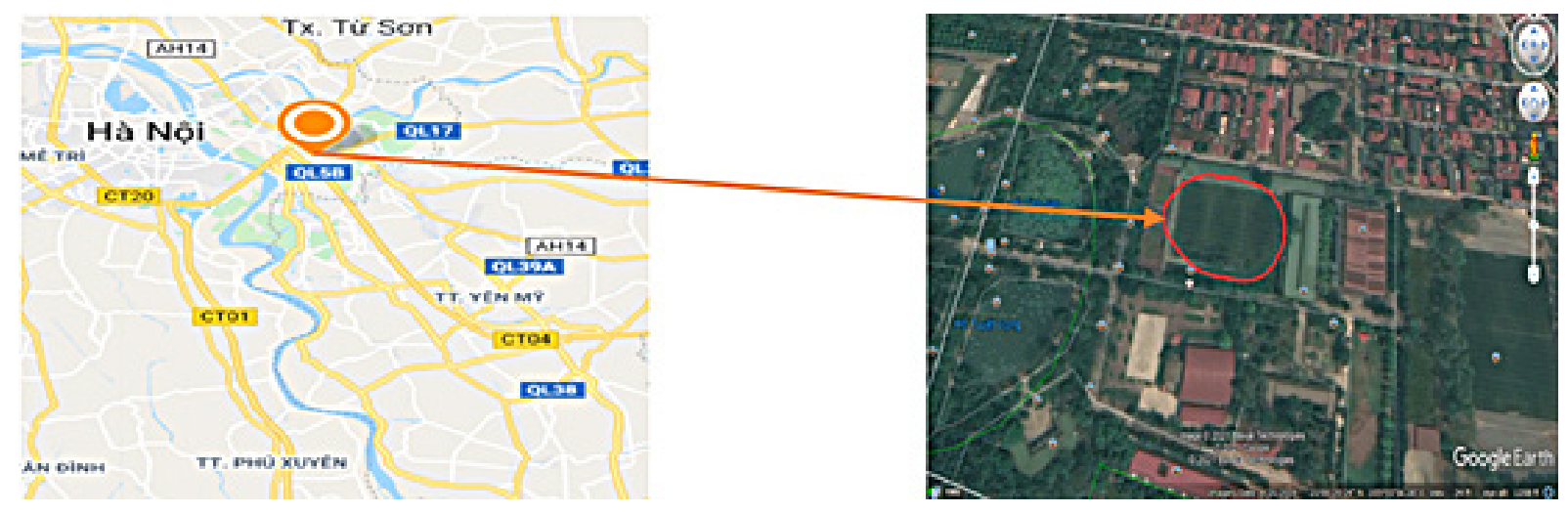

Figure 1. Location of the experimental area 
HT8 requires a growth time of between 105 and 110 days, is typically high-yielding (6.0-6.5 t/ ha) and disease-resistant, and produces good rice quality. The average weight of 1,000 seeds is around 23.8-24.3 grams.

\section{Field soil samples}

The soil samples were taken from the topsoil at depths of $0-20 \mathrm{~cm}$ in Hung Yen province, located in the centre of the Red River Delta; then, they were air-dried and sieved to $<2 \mathrm{~mm}$. The obtained soil samples had the EC values ranging from $0.128-0.155 \mathrm{mS} / \mathrm{cm}$, salinity of $0.1 \%$, $\mathrm{pH}$ of 6.5-6.7, and cation-exchange capacity (CEC) of $14.5-14.8 \mathrm{mmol}_{+} / \mathrm{kg}$.

The samples were analysed for physical and chemical characteristics, such as CEC, organic carbon content, and phosphorus and nitrogen content, using methods including ammonium acetate, Walkley-Black, and Kjeldahl.

\section{Soil properties}

The characterisation of the experiment soils under greenhouse conditions, containing 20.2\% sand, $55.3 \%$ silt, and $24.5 \%$, is presented in Table 1 .

\section{Experiment soil samples. For experiments conducted using a post system}

The soil samples for analysis were collected after 20, 40, and 60-day periods and taken at depths of $0-20 \mathrm{~cm}$. The soil sample properties were determined, including the EC of the saturated soil extract $\left(\mathrm{EC}_{\mathrm{e}}\right), \mathrm{pH}$ value, saline content, and mobile zinc (MZ) content.

\section{Grain zinc}

Grains were collected after the harvest and the zinc content was determined by digesting $0.01 \mathrm{~g}$ of rice grains from each salinity treatment with 5.0 $\mathrm{mL}$ of $\mathrm{HNO}_{3} / \mathrm{H}_{2} \mathrm{O}_{2}(4: 1, \mathrm{v} / \mathrm{v})$ using a block heater. After cooling at a temperature of $25^{\circ} \mathrm{C}$, the digested grains were transferred to a $20 \mathrm{~mL}$ volumetric flask and filtered using a Whatman filter paper.

\section{Experimental treatments under greenhouse conditions}

The pots used in the experiments were polyethylene $(P E)$ planting bags, with a surface area of $0.05 \mathrm{~m}^{2}$, bottom area of $0.03 \mathrm{~m}^{2}$, and pot height of $20 \mathrm{~cm}$. The average soil amount per pot was 25 kg. Five saline treatments $(1.5,2,3,4$, and 5\%o) were repeated three times for each cultivation crop (A, B, C symbols in Figure 2).

A typical fertiliser was prepared with a nitrogen/phosphorus/potassium (NPK) ratio of $125 \mathrm{~g}$ of compost $+1.25 \mathrm{~g} \mathrm{~N}+0.75 \mathrm{~g} \mathrm{P}_{2} \mathrm{O}_{5}+0.75 \mathrm{~g} \mathrm{~K}_{2} \mathrm{O}$ per pot, as recommended by Vietnam's Ministry of Agriculture and Rural Development for fertiliser for rice. A pesticide, namely Topsin M 70WP, was used for the prevention of disease.

For the experimental control formula (CF), irrigation water with no added salt was used. The salt concentrations of $1.5,2,3,4$, and $5 \%$ were mixed with water of $0 \%$ salinity with technical $\mathrm{NaCl}$. The amount of water was $800 \mathrm{~mL}$ per experiment with an irrigation period of 2-3 days (per experiment), using a drip irrigation system.

\section{Analysis}

The EC and $\mathrm{pH}$ values were measured using a SevenGo Duo SG23 meter (Toledo, Japan) at a depth of $0-20 \mathrm{~cm}$. The MZ content in the experiment paddy soil was analysed using a wet DTPA method, as previously described [Johnson-Beebout et al., 2009]. A 5 L volume of DTPA extracting solution was prepared by mixing $1 \mathrm{~L}$ of 0.05 $\mathrm{mol} / \mathrm{L}$ DTPA, $1 \mathrm{~L}$ of $0.1 \mathrm{~mol} / \mathrm{L}$ TEA, $1 \mathrm{~L}$ of 0.01 $\mathrm{mol} / \mathrm{L} \mathrm{CaCl}_{2}$, and $2 \mathrm{~L}$ of distilled water. After settling at room temperature for 12 hours, the initial

Table 1. Characterisation of the initial experimental soils

\begin{tabular}{|c|c|c|}
\hline Property & Unit & Values \\
\hline $\mathrm{OC}$ & $\%$ & $0.22-0.24$ \\
\hline $\mathrm{CEC}$ & $\mathrm{mmol}_{+} / \mathrm{kg}$ & $14.5-14.8$ \\
\hline $\mathrm{pH}$ & & $6.5-6.7$ \\
\hline Density & $\mathrm{g} / \mathrm{cm}^{3}$ & $1.8-1.9$ \\
\hline $\mathrm{EC}_{1: 5}$ & $\mathrm{mS} / \mathrm{cm}$ & $0.128-0.155$ \\
\hline Saline & $\% \circ$ & 0.1 \\
\hline Total $\mathrm{N}$ & $\%$ & $0.15-0.16$ \\
\hline Total $\left.\mathrm{P} \mathrm{P}_{2} \mathrm{O}_{5}\right)$ & $\%$ & $0.14-0.15$ \\
\hline Total zinc & $\mathrm{mg} / \mathrm{kg}$ & $30.1-31.2$ \\
\hline Mobile zinc & $\mathrm{mg} / \mathrm{kg}$ & $6.8-7.5$ \\
\hline $\begin{array}{c}\mathrm{Ca}^{2+} \\
\text { exchangeable }\end{array}$ & $\mathrm{mg} / \mathrm{kg}$ & $6.2-6.8$ \\
\hline $\begin{array}{c}\mathrm{Mg}^{2+} \\
\text { exchangeable }\end{array}$ & $\mathrm{mg} / \mathrm{kg}$ & $6.1-6.3$ \\
\hline $\begin{array}{c}\mathrm{Na}^{+} \\
\text {exchangeable }\end{array}$ & $\mathrm{mg} / \mathrm{kg}$ & $0.6-0.7$ \\
\hline $\mathrm{K}^{+}$exchangeable & $\mathrm{mg} / \mathrm{kg}$ & $0.2-0.3$ \\
\hline
\end{tabular}

EC: electrical conductivity of the saturated-soil extract; CEC: cation exchange capacity; OM: organic matter 

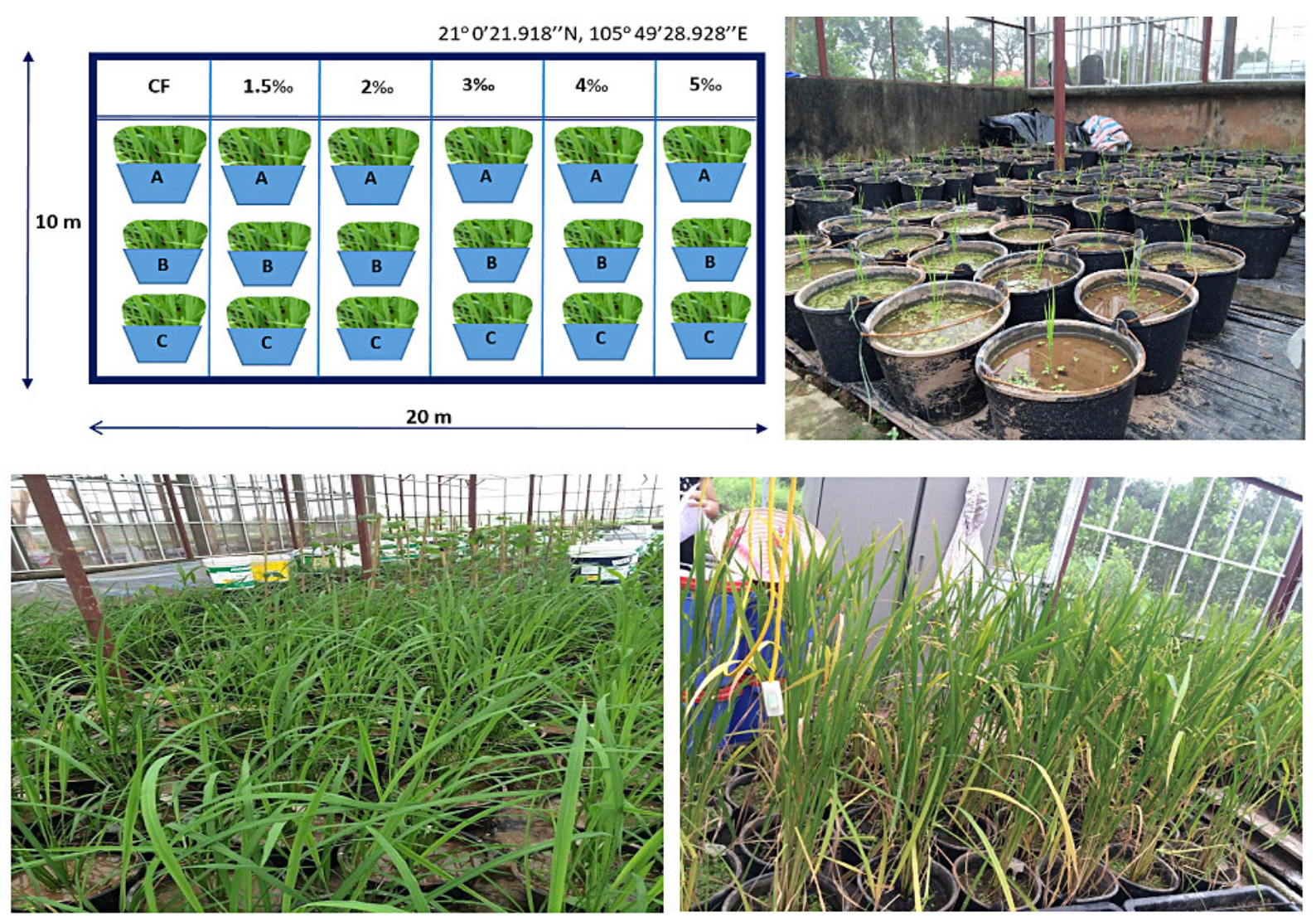

Figure 2. Scheme and photographs of the experimental design

$\mathrm{pH}$ was 4.4. The solution was adjusted to $\mathrm{pH} 7.3$ using concentrated $\mathrm{HCl}$. A dry soil $10 \mathrm{~g}$ sample was mixed with $20 \mathrm{~mL}$ of DTPA extracting solution in a $125 \mathrm{~mL}$ Erlenmeyer flask and agitated with a shaker (KS 3000i, IKA, Germany) at 250 rpm at a constant temperature of $25^{\circ} \mathrm{C}$ for two hours. The suspended solution was then filtered through a filter paper (Whatman No.42, UK). The $\mathrm{Zn}$ concentrations were measured by inductively coupled plasma mass spectrometry (ICP-MS; Agilent Model 7500a, Agilent Technologies, USA).

Growth indicators, including plant height, leaf length, and leaf width were determined after 20, 40, and 60 days. Plant height was measured as the distance from the ground to the highest leaf tip, and leaf length was measured from the petiole to the tip. Grain productivity was determined after the harvest.

\section{Statistical analysis}

All statistical analyses of the data were performed using Microsoft Excel version 5.5 (Microsoft, USA). Each value represented the average of three replications. The data was subjected to analysis of variance (ANOVA), and significant differences in mean values were determined using Duncan's multiple range test $(\mathrm{P}<0.05)$.

\section{RESULTS AND DISCUSSION}

\section{Irrigation water properties}

The tap water used to dissolve $\mathrm{NaCl}$ for irrigation was determined according to standard methods, with parameters including $\mathrm{pH}$, total nitrogen (T-N), total phosphorus (T-P), calcium $\left(\mathrm{Ca}^{2+}\right)$, magnesium $\left(\mathrm{Mg}^{2+}\right)$, sodium $\left(\mathrm{Na}^{+}\right)$, potassium $\left(\mathrm{K}^{+}\right)$, chloride $\left(\mathrm{Cl}^{-}\right)$, sulphate $\left(\mathrm{SO}_{4}^{2-}-\mathrm{S}\right)$, nitrate $\left(\mathrm{NO}_{3}^{-}-\mathrm{N}\right)$, and $\mathrm{Zn}$ ion content $\left(\mathrm{Zn}^{2+}\right)$, as shown in Table 2 .

Table 2 shows that the average $\mathrm{pH}$ value ranged from 8.03 to $8.38, \mathrm{Cl}^{-}$ion content from 8.79 to $9.21 \mathrm{mg} / \mathrm{L}$, and $\mathrm{Zn}^{2+}$ ion content between 0.068 and $0.077 \mathrm{mg} / \mathrm{L}$ in the irrigation water used for the experiment. The remaining parameters were: $\mathrm{Ca}^{2+} 24-25 \mathrm{mg} / \mathrm{L} \mathrm{Mg}^{2+}$ 6.73-6.88 mg/L, Na $\mathrm{Na}^{+} 2.73-2.86 \mathrm{mg} / \mathrm{L}, \quad \mathrm{K}^{+}$ $0.58-0.62 \mathrm{mg} / \mathrm{L}, \mathrm{S}_{-} \mathrm{SO}_{4}^{2-} 4.65-4.78 \mathrm{mg} / \mathrm{L}$, and $\mathrm{N}-\mathrm{NO}_{3}-1.59-1.63 \mathrm{mg} / \mathrm{L}$.

\section{Salinity accumulation in soil}

The EC and saline accumulation data obtained from the pot soil system at the end of the experiment, following five salinity treatments during the spring and summer seasons, are presented in Figure 3. 
Table 2. Properties and contents of irrigation water used in the experiment ( $\mathrm{mg} / \mathrm{L}$ )

\begin{tabular}{|c|c|c|c|c|c|c|c|c|c|c|}
\hline Season crop & Salinity (\%o) & $\mathrm{pH}$ & $\mathrm{Ca}^{2+}$ & $\mathrm{Mg}^{2+}$ & $\mathrm{Na}^{+}$ & $\mathrm{K}^{+}$ & $\mathrm{Cl}^{-}$ & $\mathrm{SO}_{4}{ }^{2-}-\mathrm{S}^{-}$ & $\mathrm{NO}_{3}{ }^{-}-\mathrm{N}$ & $\mathrm{Zn}^{2+}$ \\
\hline Spring 2019 & 0 & 8.03 & 24 & 6.72 & 2.86 & 0.58 & 9.21 & 4.78 & 1.57 & 0.077 \\
\hline Summer 2019 & 0 & 8.21 & 25 & 6.88 & 2.73 & 0.76 & 8.94 & 4.65 & 1.63 & 0.068 \\
\hline Spring 2020 & 0 & 8.38 & 24 & 6.73 & 2.84 & 0.62 & 8.79 & 4.71 & 1.49 & 0.074 \\
\hline
\end{tabular}

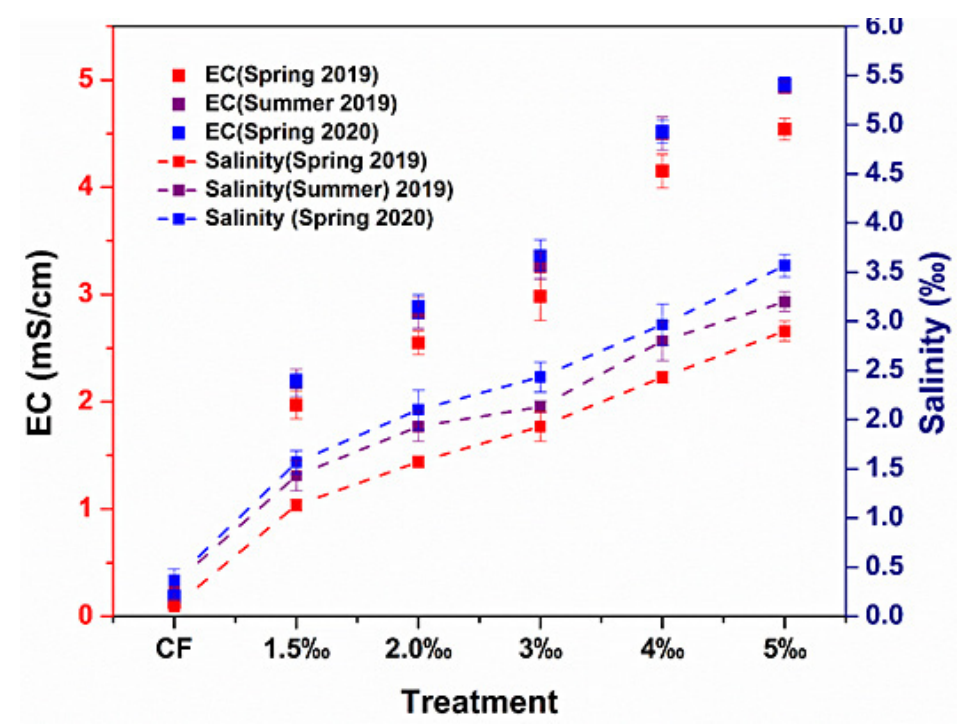

Figure 3. EC and saline accumulation in soil

Figure 3 shows that the conductivity of the soil changed slightly from $0.13 \mathrm{mS} / \mathrm{cm}$ to $0.17 \mathrm{mS} / \mathrm{cm}$ of the CF in spring and summer, respectively. Howev$\mathrm{er}$, the salt accumulation in the soil clearly increased with experimental treatments. The EC value of the soil increased to $1.97-2.20 \mathrm{mS} / \mathrm{cm}$ following the $1.5 \%$ treatment. The salt levels in soils increased with higher salinity levels in the irrigation water. For example, EC increased from 4-5.7 times in the $2 \%$ and $3 \%$ irrigation treatments. Following this trend, the EC of soils with 4\% and 5\%o treatments increased sharply to above $4 \mathrm{mS} / \mathrm{cm}$. Remarkably, the 5\%o treatment resulted in EC as high as $4.54-$ $4.96 \mathrm{mS} / \mathrm{cm}$ with a salinity increase to $3.6 \%$, which is 36 times greater than that of the $\mathrm{CF}$ (at $0 \%$ ). From the results, it can be seen that salinity in the irrigation water increased by 2 and 3 times, and EC in the root zone increased by around 1.7 and 3.3 times. On the basis of the average salt accumulation in the experiment soils, the EC of the summer crops was $0.21-0.38 \mathrm{mS} / \mathrm{cm}$ greater compared to the spring crops. Thus, the salinity of the irrigation water increased by $1 \%$, and $\mathrm{EC}$ of the soil increased by an average $1.2 \mathrm{mS} / \mathrm{cm}$ in this experiment.

The irrigation water salinity had a significant effect on the EC of the soil [Feng et al., 2017]. Greater salt accumulation in the paddy soil was observed after a long application of saline water irrigation, and this led to increasing the salt levels in the soil. Thus, salt accumulates due to the salt content in water. Where the salt content of the irrigation water is high, the salt accumulation in the soil is greater, which explains the EC value increase in the irrigation treatments with a higher salt content. Furthermore, salt accumulation is also dependent on length of irrigation time. A previous study demonstrated that salt accumulation can occur even at low salt concentrations (EC of $0.3 \mathrm{mS} / \mathrm{cm}$ ) under continuous irrigation treatment [Kim et al., 2016]. In another study, floodwater irrigation experiments in paddy fields with EC levels above $2 \mathrm{mS} / \mathrm{cm}$ caused a yield loss of up to $1 \mathrm{t} / \mathrm{hm}^{2}$ [Asch \& Wopereis, 2001]. The experiment results are consistent with that study and indicated that EC in spring 2019 was lower than in summer 2019, and EC in summer 2019 was lower than in spring 2020.

\section{Effect of salinity on rice growth}

In order to clarify the effect of saline irrigation on the plant growth rates, for each salinity treatment, growth parameter measurements were performed after 20, 40, and 60 days of treatment in the spring and summer crops (2019), and spring crop (2020). Measurements 
were based on leaf area indices, such as length and width, and plant height. The number of rice plants observed per season was 36 , of which 18 plants were of normal growth, six were of slow-growth, and 12 plants were under-grown at the end of the observed period.

\section{Leaf length}

Plant leaf length and width were measured to determine the leaf growth under saline conditions. The experiment results showed that 1.5, 2, 3,4 , and $5 \%$ saline irrigation treatments reduced leaf length by $12.6 \%, 25.4 \%, 34.9 \%, 49.2 \%$, and $60.3 \%$, respectively, compared to the CF (leaf length in the $\mathrm{CF}$ was $62 \mathrm{~cm}$ with width of 2.2 $\mathrm{cm}$ ); for example, leaf length of the 1.5, 2, 3, 4 , and $5 \%$ treatments was $4,7,13,21$, and 35 $\mathrm{cm}$ shorter, respectively, in spring 2019. This result indicates that there is a greater reduction in leaf length in the $4 \%$ and $5 \%$ treatments. Under salinity irrigation conditions, large salt amounts from the water can enter plant tissues and cause nutrient imbalances which lead to a reduction in the uptake of other nutritional elements [Kim et al., 2016]. The salt accumulation leading to the soil EC results of the $4 \%$ and $5 \%$ treatments was above $3 \mathrm{mS} / \mathrm{cm}$ (Figure 3). The salinity threshold level of the rice plant is less than $3.0 \mathrm{mS} /$ $\mathrm{cm}$ [FAO, 2006]; thus, a salt stress environment above $3.0 \mathrm{mS} / \mathrm{cm}$ can have a negative influence on the rice plant growth. The results also indicate that leaf development is most affected by the $4-5 \%$ salt content, whereby leaf width was observed to be 1.2-1.6 times shorter (measured in $\mathrm{cm}$ ) compared to the other three treatments $(1.5,2$, and $3 \%$ ) (see Figure 4$)$.

\section{Plant height}

The study results show that different salinity concentrations cause disparate plant height development. The difference in height increase over the study period due to various irrigation treatments was statistically significant at 5\%. The height growth reduction by salinity can be clearly observed as the difference in plant height after several weeks between treatments. Salt accumulation in the leaves affects stomatal closure, which can cause temperature increases in the leaves and lead to inhibition of shoot elongation, which affects plant height [Rajendran et al., 2009]. For instance, using irrigation water with no salinity $(0 \%)$, rice plants reached an optimal height of $88 \mathrm{~cm}$ with an average increase of $12.8 \%$ during 40 days under greenhouse conditions (Table 3). Lesser plant height reduction was observed following the $1.5 \%$, $2 \%$, and $3 \%$ treatments, while the $5 \%$ o treatment resulted in the most significant decrease (30.1 to $46.5 \%$ ) with a plant height of 61 $\mathrm{cm}$ in spring and $47 \mathrm{~cm}$ in summer.

The results of the present study demonstrate that rice is highly sensitive to salt, with severe effects even at $1.5 \%$ salinity, which is comparable to a previous study [Razzaq et al., 2020] which reported decreased rice density and grain production under greenhouse conditions and in field trials. Table 3 shows that increasing salinity is inversely proportional to plant height. No significant differences in plant height were observed between the $\mathrm{CF}$ and $1.5 \%$ treatments $(\mathrm{P}=0.08,0.16$, and 0.09 respectively) at day 20 . However, at the end of the treatment (day 60), plant height was shorter after the $1.5 \%$ treatment by about $10 \mathrm{~cm}$. At higher salinity concentrations, such as treatments of $2 \%$
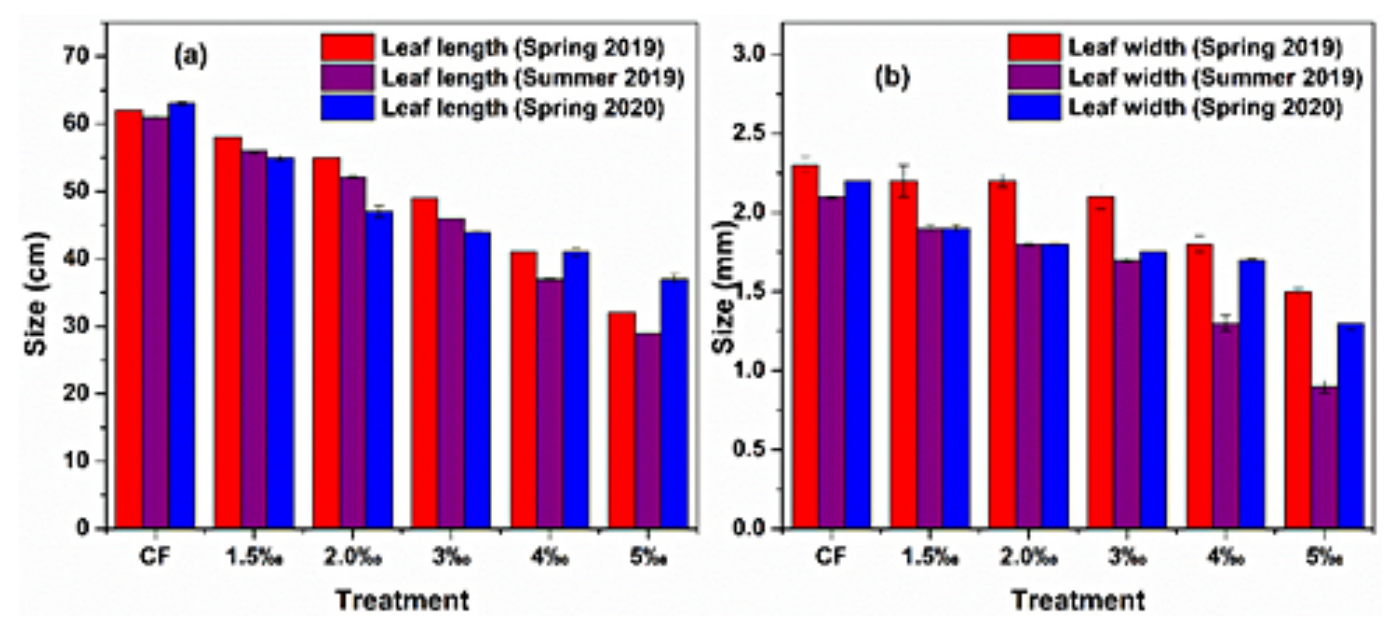

Figure 4. Effect of salinity on leaf growth 
Table 3. Rice growth parameters after 20, 40, and 60 days

\begin{tabular}{|c|c|c|c|c|}
\hline \multirow{2}{*}{ Treatments } & \multicolumn{3}{|c|}{ Average plant height $(\mathrm{cm})$} & \multirow{2}{*}{${ }^{*} \mathrm{P}$} \\
\hline & 20 days & 40 days & 60 days & \\
\hline \multicolumn{5}{|c|}{ Spring 2019} \\
\hline CF & 78 & 86 & 88 & - \\
\hline $1.5 \%$ & 71 & 76 & 78 & 0.080 \\
\hline $2 \%$ & 66 & 72 & 76 & 0.040 \\
\hline $3 \%$ & 66 & 71 & 73 & 0.024 \\
\hline $4 \%$ & 58 & 63 & 67 & 0.006 \\
\hline $5 \%$ & 56 & 58 & 61 & 0.006 \\
\hline \multicolumn{5}{|c|}{ Summer 2019} \\
\hline CF & 75 & 79 & 83 & - \\
\hline $1.5 \%$ & 68 & 74 & 77 & 0.164 \\
\hline $2 \%$ & 62 & 65 & 69 & 0.087 \\
\hline $3 \%$ & 57 & 62 & 67 & 0.404 \\
\hline $4 \%$ & 51 & 54 & 58 & 0.103 \\
\hline $5 \%$ & 43 & 45 & 47 & 0.025 \\
\hline \multicolumn{5}{|c|}{ Spring 2020} \\
\hline CF & 76 & 82 & 87 & - \\
\hline $1.5 \%$ & 69 & 73 & 76 & 0.087 \\
\hline $2 \%$ & 61 & 64 & 68 & 0.044 \\
\hline $3 \%$ & 55 & 59 & 65 & 0.266 \\
\hline $4 \%$ & 49 & 53 & 55 & 0.112 \\
\hline $5 \%$ & 41 & 44 & 46 & 0.021 \\
\hline
\end{tabular}

$* \mathrm{P}=$ probability

and $32 \%$, height was significantly impacted, and these treatments resulted in shorter plant height (62-65 cm, 59-64 cm, respectively) during the summer 2019 and spring 2020 crops compared to those observed in the spring $2019 \mathrm{crop}(71-72 \mathrm{~cm})$ after 40 days. When the salinity level increased to $4 \%$, the high $\mathrm{Na}^{+}$content in the irrigation water further hindered the plant growth, with an average plant height of only $55-67 \mathrm{~cm}$ for all three seasonal crops after 60 days. Furthermore, the observations at 5\%o treatment showed that the plant height decreased dramatically by one-third compared to the $\mathrm{CF}$ during the entire period of study. Comparison of the experiment results in the three crops indicates that the influence of long-term saline accumulation leads to a decrease in growth of the rice plant. This is illustrated by the plant height and leaf length decreasing in the order spring $2020>$ summer 2019 $>$ spring 2019. The average growth parameters of the previous crop in the sequence compared to the next crop were reduced by $10.12-11.98 \%$.

For the plant growth index, the studies of salinity have shown reduced growth rates, height, weight, and grain number of rice plants, thus decreasing biomass production and causing low grain yield
[Razzaq et al., 2020]. The most harmful impact of salinity stress is the $\mathrm{Na}^{+}$and $\mathrm{Cl}^{-}$accumulation in rice plant tissues and paddy soil [Cominelli et al., 2013]. The ability to tolerate increased $\mathrm{Na}^{+}$concentrations limits the nutrition metabolism in the leaves [Yang Y et al., 2018]. Salt concentrates in the leaves can be damaging to leaf cells [Munns \& Tester, 2008]; specifically, an imbalance between plant and soil is caused by greater accumulation of $\mathrm{Na}^{+}$and $\mathrm{Cl}^{-}$ions, which can lead to physiological disorders in plants [Kronzucker et al., 2013]. High salinity concentrations may also reduce the water and nutrition uptake due to salt accumulation in the root system, as witnessed predominantly during periods of drought. Salt toxicity reduces the osmotic role and nutrient exchange function in plant cells [Kronzucker et al., 2013]. In addition, an overabundance of $\mathrm{Na}^{+}$ions damages plant cell membranes and can dry the leaves. Furthermore, decreasing the nutrient uptake causes leaf development to become slower and leaf ageing/drying to become faster; thus, reduced leaf density decreases the speed of photosynthesis, resulting in lower grain quality and productivity [Cominelli et al., 2013].

Thus, the growth of rice crops is limited by higher salinity concentrations and increased competition with $\mathrm{Na}^{+}$ions, resulting in decreased nutrition uptake [Islam et al., 2007]. These study results are consistent with previous publications on the effect of salt stress on root and shoot lengths. In the cation-exchange process, increasing the $\mathrm{Na}^{+}$ion content in paddy soil reduces the absorption capacity for other cations, including $\mathrm{K}^{+}, \mathrm{Ca}^{2+}$, and $\mathrm{Mg}^{2+}$ macronutrients [Nishimura et al., 2011]. Competition with $\mathrm{Na}^{+}$ions causes $\mathrm{Mg}^{2+}, \mathrm{Ca}^{2+}$, and $\mathrm{K}^{+}$deficiency to inhibit rice growth and development, limiting nutrient uptake and impeding leaf growth [Roy et al., 2014]. As a result, higher saline conditions contribute to shorter plant height.

No significant difference was observed between salinity levels at $0 \%$ and $1.5 \%$ ( $(\mathrm{P}=0.08)$; thus, it can be concluded that salinity $\leq 1.5 \%$ o has little influence on plant height. However, when the salinity levels exceed $1.5 \%$, plant height is significantly impacted $(\mathrm{P}<0.05)$, confirming that decreased plant height is due to the effects of salinity.

\section{Effect of salinity on grain yield}

The effect of salinity on yield was determined by the number of flowers per plant, number of seeds per flower, thousand-grain weight, and grain yield. 
The influence of salinity on grain number is different between salinity levels. Higher salinity concentrations cause weaker growth. Grain yield was found to vary with each salinity treatment $(\mathrm{P}$ $<0.05)$. Specifically, a yield of $4.43 \mathrm{t} / \mathrm{ha}$ was obtained with CF (0\%) in the spring 2019 crop, and 4.21 and $4.38 \mathrm{t} / \mathrm{ha}$ in the summer 2019 and spring 2020 crops, respectively. These observations indicate that grain yield decreased as treatments with increasing levels of salinity were applied. When salinity concentrations are higher than $1.5 \%$, decreasing rice grains number occurs. The results in Table 4 show that the salinity concentrations of $1.5 \%$ decreased yields by $11.9 \%$ and $11.6 \%$ in spring and summer 2019, respectively, and sharply decreased yield, by $16.9 \%$, in spring 2020 .

Furthermore, yields with $2 \%$ salinity treatment decreased by $23.5 \%, 26.4 \%$ and $31.5 \%$ in the spring and summer 2019 and spring 2020 experimental crop seasons, respectively, demonstrating the significant influence of salinity above $2 \%$ [Ezeaku et al., 2015]. The 3\%o salinity treatment reduced yield significantly, by around $43.8 \%$ in the spring 2019 crop and $44.7 \%$ in the summer 2019 crop. Although the effects of salinity on seasonal yields differed, such as $64.38 \%$ in spring 2020 ( $3 \%$ treatment), it was noted that the application of saline water irrigation for long periods adversely affected rice productivity. With $4 \%$ salinity treatment, yield was only $27.3 \%$ and $25.9 \%$ in spring and summer seasons 2019, respectively; it was $18.9 \%$ in spring 2020 . Notably, $5 \%$ treatment in all seasons stopped growth completely, with no grain produced. Thus, it is important to maintain salinity under $4 \%$ o to yield any grain at all.

As observed, increasing salinity in irrigation water affects rice growth, which in turn limits the rice grain yield. Specifically, when the salinity levels reach $2 \%$ and $3 \%$, rice yield reduces to only between one-quarter and one-half of that obtained with $1.5 \%$ salinity.
Salt accumulation in soil leads to low rice grain yields and weak resistance [Hussain et al., 2017]. When subject to saline stress, rice roots are significantly affected by the uptake of salt, which subsequently leads to ion and nutrient imbalances. The study results show that different salinity concentrations affected the plant height of the HT08 rice variety. This finding accords with other rice studies, indicating that salinity adversely affects the growth parameters of most plant cultivars. Higher salinity concentrations increase the competition with $\mathrm{Na}^{+}$ions, resulting in decreased nutrition uptake. These results are consistent with previous publications on the effects of salt stress on root and shoot lengths.

For cultivation yield, previous study findings demonstrate incomplete seed development resulting from nutrient deficiency caused by salt stress [Wei et al., 2019]. Water plays a vital role in dissolving nutrients in the soil, and capillary action transports absorbed nutrition in the plant. Salt stress hinders osmosis in the root system and causes the phenomenon of water deficiency in the plant. Thus, water deficiency impedes the uptake of nutrients, including nitrogen, phosphorus, potassium, calcium, and zinc [Chawla et al., 2013]. Under salinity stress conditions, the changes in the physiological properties of paddy soil, such as density and compression, can disrupt the physiological parameters in the root system, causing root damage leading to insufficient nutrition uptake and, as a result, a low yield [Zhu et al., 2018].

Other experiments have concluded that the pollen-keeping ability is also decreased by the salinity effect. Salt stress has a dramatic impact on crop growth and grain productivity, and is the primary factor responsible for yield losses in many countries [Wessells \& Brown 2012]. Thus, in irrigation water significantly affects the rice crop production. Although each different rice variety has its own salinity tolerance, $\mathrm{Na}+$ ions mainly cause plant toxicity which prevents the

Table 4. Grain yield

\begin{tabular}{|c|c|c|c|c|c|c|c|}
\hline Treatments & $\begin{array}{c}\text { Average number } \\
\text { of flowers per } \\
\text { tree }\end{array}$ & $\begin{array}{c}\text { Average } \\
\text { seeds number } \\
\text { per flower }\end{array}$ & $\begin{array}{c}\text { Imperfect } \\
\text { grain ratio } \\
(\%)\end{array}$ & $\begin{array}{c}\text { Average } \\
\text { mass of } 1000 \\
\text { sheed }(\mathrm{g})\end{array}$ & $\begin{array}{l}\text { Grain yield of } \\
2019 \text { Spring } \\
\text { season (t/ha) }\end{array}$ & $\begin{array}{l}\text { Grain yield of } \\
2019 \text { Summer } \\
\text { season (t/ha) }\end{array}$ & $\begin{array}{l}\text { Grain yield of } \\
2020 \text { Spring } \\
\text { season (t/ha) }\end{array}$ \\
\hline $\mathrm{CF}$ & 4.6 & 169 & 14.8 & 22.6 & 4.43 & 4.21 & 4.38 \\
\hline $1.5 \%$ & 4.3 & 142 & 16.7 & 22.0 & 3.81 & 3.72 & 3.68 \\
\hline $2.0 \%$ & 3.9 & 123 & 20.4 & 18.3 & 3.39 & 3.10 & 3.02 \\
\hline $3 \%$ & 2.5 & 97 & 33.6 & 15.1 & 1.94 & 1.88 & 1.56 \\
\hline $4 \% 0$ & 1.4 & 38 & 54.9 & 13.4 & 1.21 & 1.09 & 0.83 \\
\hline $5 \%$ & 0 & 0 & - & - & 0 & 0 & 0 \\
\hline
\end{tabular}


nutrient uptake. Lack of plant nutrition reduces photosynthesis and the pollination process, and helps explain the impact of salt on grain crop production. Moreover, high salinity levels can completely prevent plant growth and pollination [Zhu et al., 2018]. Various studies have also reported that crop yield declines due to increasing salinity in irrigation water [Wei et al., 2019]. Salinity also directly impacts cell expansion and division in correlation with reduced leaf area [Shrivastava \& Kumar, 2015]. In the present study, under greenhouse conditions, grain yield was $4.21 \mathrm{t} / \mathrm{ha}$ in summer and $4.43 \mathrm{t} / \mathrm{ha}$ in spring. These results agree with the previous reports that salt stress can cause panicle sterility in the fertilisation process, leading to reduced grain production [Islam et al., 2007].

The MZ nutrient uptake by plants is present in soil solution. The results show that MZ content in the soil decreased with the salt irrigation treatments. In explaining this phenomenon, the published studies indicate that using saline irrigation water has a negative influence on $\mathrm{P}$, $\mathrm{K}^{+}, \mathrm{Fe}, \mathrm{Ca}^{2+}$ and $\mathrm{Zn}^{2+}$ nutrients in paddy soils, and $\mathrm{Zn}$ deficiency occurs with increased salt stress [Alloway, 2008]. One adverse effect of salt stress on plant growth includes increased soil compactness and hardness, which prevent roots from developing into a sufficient root system [Machado \& Serralheiro, 2017]. As compression is increased by salt stress, the level of oxygen is reduced in paddy soil, causing decreased redox potential and the formation of precipitates such as $\mathrm{ZnS}$.

\section{Effect of salinity on the $M Z$ content in paddy soil}

In this study, the results show that salinity affects the $\mathrm{MZ}$ micronutrients $\left(\mathrm{Zn}^{2+}, \mathrm{Zn}(\mathrm{OH})^{+}\right)$in paddy soil, which are important for plant growth. As treatment with increasing salinity was applied, competition between $\mathrm{Na}^{+}$ions and $\mathrm{MZ}$ also increased. Compared to $\mathrm{MZ}=6.8-7.5 \mathrm{ppm}$ following the CF treatment, MZ decreased by around $8.86-9.23 \%$ after the $2 \%$ treatments and 51.3 to $81.53 \%$ after applying the 3 to $5 \%$ treatments in the 2019-2020 crop seasons, respectively.

Overall, increasing salinity level causes reduced $\mathrm{MZ}$ concentration. In this study, the MZ content in experimental soils under 1.5-5\% salt treatments decreased by $3.12-81.53 \%$ compared to CF. These results can be attributed to irrigation with high salinity water changing soil osmotic potential, making it difficult for plants to absorb water and to take up nutrition. Increasing the $\mathrm{Na}+$ ion content in soil leads to an increase in soil $\mathrm{pH}$ [Wei et al., 2019]. The MZ content increases under the conditions of decreasing soil $\mathrm{pH}$ values [Alloway, 2008]. The micronutrient deficiency in soils, because they were absorbed on the surface of soil colloidal particulars, occurs commonly in saline soils with high $\mathrm{pH}$ values [Zhu et al., 2004]. When the soil $\mathrm{pH}$ values increase, soluble $\mathrm{Zn}$ forms complexes with hydroxyl ion to form $\mathrm{Zn}(\mathrm{OH})_{2}$ minerals, and this can decrease MZ in the soil. The soil conditions that cause zinc deficiency in crops can be attributed to the reasons including high salt concentration (saline soils) [Alloway, 2008].

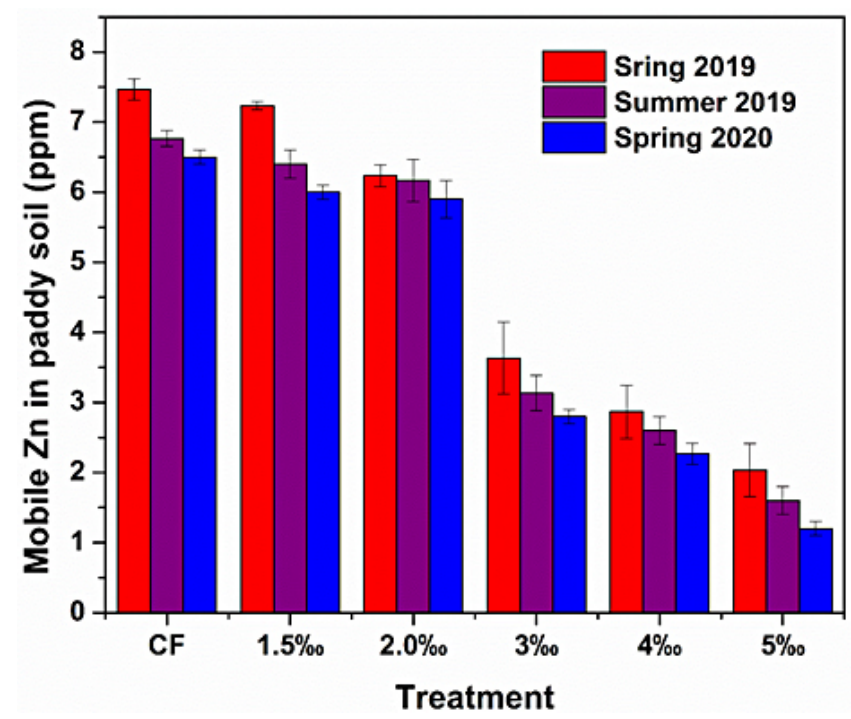

Figure 5. Effect of salinity on mobile zinc in paddy soil 
$\mathrm{Zn}$ is an essential micronutrient for healthy plant growth and optimum yield in rice production [Alloway, 2008]. Salt stress in the root region causes detrimental biochemical and morphological changes that result in decreased nutrient uptake, including $\mathrm{Zn}$, by the rice plant, and can reduce rice yield by over $20 \%$ [Machado \& Serralheiro, 2017]. Because salinity alters the physical properties of soil, the root systems of rice plants become compressed, reducing both oxygen levels and redox potential. Furthermore, micronutrient deficiency caused by salinity stress is a common phenomenon in flood soils due to the existence of mobile micronutrients, such as $\mathrm{Zn}$, which depend on the solubility level, $\mathrm{pH}$, and redox potential of the soil environment [Farouk et al., 2019]. Zn deficiency causes the physiological stress phenomenon [Vojodi et al., 2018] because the physiological and metabolic processes in plants cell require Zn [Fang et al., 2008].

\section{Effect of salinity on the $\mathrm{Zn}$ content in grain}

The effect of salinity concentration on the uptake of $\mathrm{Zn}$ in rice grains was found to be significant $(\mathrm{P}<0.05)$ in all three seasons. The treatment with $0 \%$ salinity $(\mathrm{CF})$ resulted in significantly higher uptake of $\mathrm{Zn}$ in the rice grain $(\mathrm{P}<0.05)$ compared to the other salt treatments. Subsequently, the $\mathrm{Zn}$ concentration in the rice grain decreased to 0.87 ppm with the $1.5 \%$ o treatment and reduced dramatically by 36.06 to $38.02 \%$ and 62.79 to $69.28 \%$ with the 2 and 3\%o treatments, respectively. The $4 \%$ treatment decreased the $\mathrm{Zn}$ content further, by around $82.31-85.71 \%$, while rice grains after the $5 \%$ treatment contained no zinc at all (Figure 6).
Zn deficiency was demonstrated to reduce auxin which results in shortleaf and leaf size limitation [Broadley et al., 2007]. Besides, reducing the auxin content can be one of factors to growth retardation of root and shoot and limits $\mathrm{Zn}$ uptake [Mroue et al., 2018]. Reducing the $Z n$ uptake can lead to lack of $\mathrm{Zn}$ nutrition in rice. Consistent with the obtained results, previous studies have also reported that the absorption of $\mathrm{Zn}$ in rice and other crops decreased with elevated soil salinity [Amanullah \& Inamullah, 2016], whereby excessive soluble salts even decrease $\mathrm{Zn}$ in leaf tissue. This phenomenon can be caused by $\mathrm{Na}^{+}$and $\mathrm{Cl}^{-}$ions in plant tissue being in competition with $\mathrm{Zn}^{2+}$, whereby an imbalance of the Zn uptake occurs [Faisal et al., 2020]. Furthermore, decreased $\mathrm{MZ}$ in soil is also a reason for decreased $\mathrm{Zn}$ content in grain [Bala et al., 2019]. Grain $\mathrm{Zn}$ deficiency can affect the human diet. Such effects pose considerable risks to the cognitive development of children in countries such as Vietnam, as they depend mainly on rice as their primary source of nutrition [Wessells \& Brown, 2012].

\section{CONCLUSIONS}

In conclusion, under experimental greenhouse conditions, the results show that saline irrigation water significantly affects soil properties, and in turn, growth, yield, and the available $\mathrm{Zn}$ content in paddy rice. The saline accumulation trend sharply increased in paddy soil with $4-5 \%$ irrigation treatments $(4.15-4.96 \mathrm{mS} / \mathrm{cm})$. Salinity impacts various parameters of rice plants, including leaf length and plant height; in particular,

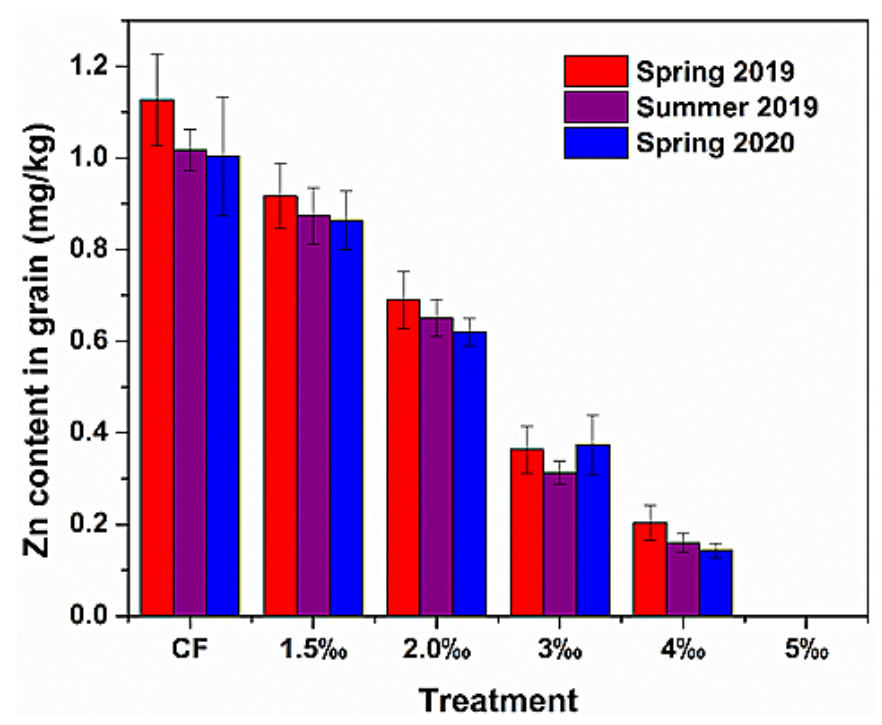

Figure 6. The $\mathrm{Zn}$ content in grain 
the 5\% irrigation treatment caused shorter plant height by one-third compared to the CF treatment ( $0 \%$ o salinity), subsequently inhibiting grain production. Increased salinity levels also reduced $\mathrm{MZ}$ in the paddy soil by $51.3-85.31 \%$ following the $3 \%$, $4 \%$ and $5 \%$ salt irrigation treatments, respectively, and the 2,3 , and $4 \%$ salinity treatments reduced the $\mathrm{Zn}$ content in rice grains by $36.27 \%, 69.28 \%$, and $85.71 \%$, respectively. This study evaluated rice quality in the context of salted irrigation water, and the results may provide reference for the regions considering the effects of using saline irrigation water.

\section{REFERENCES}

1. Alloway B.J. 2008. Zinc in Soils and Crop Nutrition. IZA and IFA, Brussels, Belgium and Paris, France

2. Amanullah, Inamullah. 2016. Dry Matter Partitioning and Harvest Index Differ in Rice Genotypes with Variable Rates of Phosphorus and Zinc Nutrition. Rice Sci, 23(2), 78-87.

3. Asch F., Wopereis M.C.S. 2001. Responses of fieldgrown irrigated rice cultivars to varying levels of floodwater salinity in a semi-arid environment. F Crop Res, 70, 127-137.

4. Bala R., Kalia A., Dhaliwal S.S. 2019. Evaluation of efficacy of $\mathrm{ZnO}$ nanoparticles as remedial zinc nanofertilizer for rice. J Soil Sci Plant Nutr, 19, 379-389.

5. Broadley M.R., White P.J., Hammond J.P., Zelko I., Lux A. 2007. Zinc in plants. New Phytol 173, 677-702.

6. Carmen B. \& Roberto D. 2011. Soil Bacteria Support and Protect Plants Against Abiotic Stresses. In: Abiotic Stress in Plants. IntechOpen, Rijeka.

7. Chawla S., Jain S., Jain V. 2013 Salinity induced oxidative stress and antioxidant system in salt-tolerant and salt-sensitive cultivars of rice (Oryza sativa L.). J Plant Biochem Biotechnol, 22, 27-34.

8. Cominelli E., Conti L., Tonelli C., Galbiati M. 2013 Challenges and perspectives to improve crop drought and salinity tolerance. N Biotechnol, 30, 355-361.

9. Ezeaku P., Ene J., Shehu J. 2015 Application of Different Reclamation Methods on Salt Affected Soils for Crop Production. Am J Exp Agric.

10. Fang Y., Wang L., Xin Z., Zhao L., An X., Hu Q. 2008 Effect of Foliar Application of Zinc, Selenium, and Iron Fertilizers on Nutrients Concentration and Yield of Rice Grain in China. J Agric Food Chem, 56, 2079-2084.

11. Farouk S., Al-Amri S.M. 2019 Exogenous zinc forms counteract $\mathrm{NaClinduced} \mathrm{damage} \mathrm{by} \mathrm{regu-}$ lating the antioxidant system, osmotic adjustment substances, and ions in canola (Brassica napus $\mathrm{L}$. cv. Pactol) plants. J Soil Sci Plant Nut, 19, 887-899.
12. Flowers T.J. \& Colmer T.D. 2008. Salinity tolerance in halophytes. New Phytol 179, 945-963.

13. Faisal N., Muhammad A., Muhammad A., Muhammad S., Tayyaba S., Abdullah T., Hafiz U. M.A., Wu J. 2020 Comparative Response of Two Rice (Oryza sativa L.) Cultivars to Applied Zinc and Manganese for Mitigation of Salt Stress. Journal of Soil Science and Plant Nutrition, 20, 2059-2072.

14. Hussain S., Zhang J., Zhong C., Zhu L., Cao X., Yu S., Allen B.J., Hu J., Jin Q. 2017. Effects of salt stress on rice growth, development characteristics, and the regulating ways: A review. J Integr Agric, 16, 2357-2374.

15. Islam M.Z., Mia M.A.B., Islam M.R., Akter A.A. 2007 Effect of Different Salinity Levels on Growth and Yield Attributes of Mutant Rice. J Soil Nature, 1, 18-22.

16. Johnson-Beebout S.E., Lauren J.G., Duxbury J.M. 2009. Immobilization of Zinc Fertilizer in Flooded Soils Monitored by Adapted DTPA Soil Test. Commun Soil Sci Plant Anal, 40, 1842-1861.

17. Kibria M.G., Hossain M., Murata Y., Hoque M.A. 2017 Antioxidant Defense Mechanisms of Salinity Tolerance in Rice Genotypes. Rice Sci, 24, 155-162.

18. Kim H., Jeong H., Jeon J., Bae S. 2016 Effects of irrigation with saline water on crop growth and yield in greenhouse cultivation. Water, 8(4), 127.

19. Kronzucker H.J., Coskun D., Schulze L.M., Wong J.R., Britto D.T. 2013 Sodium as nutrient and toxicant. Plant Soil, 369, 1-23.

20. Maathuis F.J.M. 2014 Sodium in plants: Perception, signalling, and regulation of sodium fluxes. Journal of Experimental Botany, 65(3), 849-858.

21. Machado R.M.A., Serralheiro R.P. 2017 Soil salinity: Effect on vegetable crop growth. Management practices to prevent and mitigate soil salinization. Horticulturae, 3(2), 30.

22. Mroue S., Simeunovic A., Robert H.S. 2018 Auxin production as an integrator of environmental cues for developmental growth regulation. J Exp Bot, 69, 201-212.

23. Munns R., Tester M. 2008 Mechanisms of Salinity Tolerance. Annu Rev Plant Biol, 59, 651-681.

24. Nishimura T., Cha-um S., Takagaki M., Ohyama K., Kirdmanee C. 2011 Survival percentage, photosynthetic abilities and growth characters of two indica rice (Oryza sativa L. spp. indica) cultivars in response to iso-osmotic stress. Spanish J Agric Res, 9(1), 262-270.

25. Razzaq A., Ali A., Safdar L.B., Zafar M.M., Rui Y., Shakeel A., Shaukat A., Ashraf M., Gong W., Yuan Y. 2020 Salt stress induces physiochemical alterations in rice grain composition and quality. J Food Sci 85, 14-20.

26. Roy S.J., Negrão S., Tester M. 2014 Salt resistant crop plants. Curr Opin Biotechnol, 26, 115-124. 
27. Shrivastava P. \& Kumar R. 2015 Soil salinity: A serious environmental issue and plant growth promoting bacteria as one of the tools for its alleviation. Saudi J Biol Sci, 22, 123-131.

28. Vietnam's Derectorate of Water resources 2020 Report on water resources, drought, water shortage and saline intrusion in the dry season in 2019-2020.

29. Vojodi L., Hassanpouraghdam M.B., Shamsi-Khotab T. 2018 The effects of common and nano-zinc foliar application on the alleviation of salinity stress in rosmarinus officinalis L. Acta Sci Pol Hortorum Cultus, 17, 65-73.

30. Wei C., Li F., Yang P., Ren S., Wang S., Wang Y., Xu Z., Xu Y., Wei R., Zhang Y. 2019. Effects of irrigation water salinity on soil properties, $\mathrm{N}_{2} \mathrm{O}$ Emission and yield of spring maize under mulched drip irrigation. Water, 11, 1548.

31. Wessells K.R. \& Brown K.H. 2012 Estimating the global prevalence of zinc deficiency: Results based on Zinc availability in national food supplies and the prevalence of stunting. PLoS One 7, e50568.

32. Zhu C., Qiang C., Huang M., Zhai Y., Lü W. 2018 Effect of alternate irrigation with fresh and slight saline water on physiological growth of summer maize in coastal reclamation area. Nongye Jixie Xuebao/Transactions Chinese Soc. Agric. Mach.

33. Yang Y. \& Guo Y. 2018. Unraveling salt stress signaling in plants. J Integr Plant Biol 60, 796-804. 